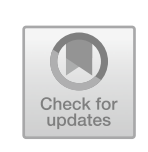

\title{
Sweden's Riksbank: Guardian of Monetary Integrity
}

\author{
Jobannes Lindvall
}

\section{The Oldest Central Bank in the World}

The Riksbank, Sweden's central bank, was established in 1668 and is the oldest central bank in the world. It has played a central role in the Swedish economy and in Swedish economic policymaking for centuries. In an era of increasing scepticism of central banks, the Riksbank enjoys a high degree of public confidence. In 2016, more than three hundred years after it began to issue paper money, the Riksbank announced that it was considering creating a new, electronic currency: the e-krona. It was the first central bank to take active steps towards issuing central-bank-backed currency for a post-coin, post-paper-money age.

Today's Riksbank is politically independent and widely respected within and outside Sweden. An institution, as defined in this volume, is 'an organizational form that reliably performs a societal task or function in a highly valued way'. Following Goodsell (2011), and building on Selznick (1957), the book's introductory chapter hypothesizes that institutions have a few important qualities in common: they are appreciated

J. Lindvall $(\bowtie)$

Lund University, Lund, Sweden

e-mail: johannes.lindvall@svet.lu.se

(C) The Author(s) 2021

A. Boin et al. (eds.), Guardians of Public Value, https://doi.org/10.1007/978-3-030-51701-4_5 
for their ability to address important social problems; they celebrate their history and employ personnel who are motivated to defend their values; and they encourage learning, adaptation and innovation. The Riksbank is a good example of a modern institution that meets these criteria, which helps to explain its status in contemporary Swedish society and abroad.

It would be wrong to infer from the Riksbank's status as an independent and widely respected institution that there is no political conflict over Swedish monetary policy or the regulation of Sweden's financial system. On the contrary, the modern Riksbank is independent and respected precisely because of conflict. For Sweden's political parties, interest organizations, and other political and economic decision-makers, the delegation of policymaking authority to the central bank serves to contain and manage conflicts over distribution and redistribution-conflicts that might otherwise become harmful to a small, open economy. Changing the nature of its often complicated relationship with the Swedish government and parliament, the bank began to play this particular role in the aftermath of Sweden's deep financial and economic crisis in the 1990s.

This chapter includes a brief account of the Riksbank's 350-year history, but it concentrates on the last few decades, when Sweden's current macroeconomic regime was established and consolidated. ${ }^{2}$ The Riksbank's path-breaking strategy after the exceptionally severe crisis in 1991-1993 features prominently in this account. This chapter also covers the Riksbank's ambitious response to the global economic downturn of 2008-2009 as well as its current attempts to introduce new approaches to monetary policy and the regulation of the payments system, notably the controversial idea of introducing a new electronic currency.

\section{Central Banks as Institutions}

The Riksbank's main offices are located in a rock-clad, cube-shaped building at Brunkebergs torg in Sweden's capital, Stockholm. Approximately 360 people work for the bank (Sveriges Riksbank 2019a: 15). Its main units are the Financial Stability Department, which analyses the performance of the financial system; the Markets Department, which manages the Riksbank's assets and trades them in accordance with the monetary policy decisions of the bank's governors; the Monetary Policy Department, which carries out the research that informs the governing board's monetary policy decisions; and the Cash and Payment Systems 
Department, which is responsible for the provision of cash and the functionality of the payments system. The bank's various departments thus contribute to achieving the bank's two goals: price stability and a safe and efficient system for making payments in the economy. ${ }^{3}$

The bank is headed by an Executive Board, which is made up of six governors appointed by the General Council, which, in turn, is appointed by parliament. Many of the bank's employees are economists, but it also employs lawyers, IT experts and communications specialists, among others.

Institutions, according to Selznick (1957), are defined by a strong reputation and public legitimacy, by a distinct identity and unique competence, and by a capacity for adaption that enables them to survive over time. As discussed in the introductory chapter, Goodsell (2011) operationalized these concepts for public agencies, emphasizing three indicators of the institutionalization process: (a) a 'reputation based on achievement', (b) ongoing 'agency renewal and learning' and (c) having an 'agency history' that is 'known and celebrated'.

As I discuss in more detail below, the Riksbank's status in contemporary Swedish society is a result of how it responded to Sweden's deep economic crisis in the 1990s (which corresponds with the first point of Goodsell's list). The modern Riksbank has proven to be an innovativesometimes even radical-organization when it comes to the means of achieving its main objectives of maintaining stable prices and securing a secure system of payments (the second point in Goodsell's list).

The Riksbank also celebrates its history and endeavours to make itself known internationally, domestically and within the bank itself (the third point in Goodsell's list). In 2018, the Riksbank celebrated its 350-year anniversary. To promote the anniversary abroad, the bank's research department contributed to a book about the history of the Riksbank in a comparative perspective, which was published by Cambridge University Press (Edvinsson et al. 2018). The bank also organized numerous public events in Stockholm and around Sweden to promote its history with domestic audiences (Sveriges Riksbank 2019a: 18-19). Within the Riksbank itself, the strategic plan that was adopted in 2014 reminded the organization of the bank's storied history; it was called En 350-airing $i$ täten (A 350-Year-Old in the Lead) (Sveriges Riksbank 2019a: 16).

Like most central banks around the world, the Riksbank seeks to maintain its operational independence from cabinet ministers and from lawmakers in parliament. Autonomy is something that all institutions 
aspire to, but it has a special meaning for central banks. In current macroeconomic thinking, shared by most policymakers, operational independence for central banks is seen as a necessary condition for effective monetary policymaking (Cukierman 1992; Marcussen 2005; for a critical perspective, see Adolph 2013).

Selznick (1957) observed that institutions can only maintain a degree of autonomy in a democratic society if they remain valued by political leaders, stakeholders and the general public. He made this observation in the middle of the twentieth century, at a time when most central banks were manifestly not operationally independent and long before central-bank independence became a widely accepted principle of good government. It is interesting to note, therefore, that modern central banks face the three challenges that Selznick mentions in a direct way. Their governors are appointed by, and report to, elected politicians in governments and parliaments; they interact directly with stakeholders such as commercial banks and other financial institutions; and they only remain effective if citizens trust them to maintain the value of money and to provide for an effective and secure system of payments.

Central banking is thus not merely a technical, engineering-like activity; it is also a communicative and social one (Hall and Franzese 1998). As Woodford (2003: 15) notes in his classic of contemporary macroeconomics, modern central banking is essentially a matter of the 'management of expectations'. Woodford (2003: 15) observes that it is 'important for the public to understand the central bank's actions, to the greatest extent possible, not only for reasons of democratic legitimacy though this is an excellent reason itself, given that central bankers are granted substantial autonomy in the execution of their task - but also in order for monetary policy to be most effective'. It would not be an exaggeration to say that central banks can only achieve their main policy objectives if they are 'institutions' in Selznick's sense-in that they enjoy the confidence of governments, corporations, social organizations and the general public.

The most important consequence of the high level of confidence that political and economic decision-makers in Sweden have had in the Riksbank is that since the late 1990s, wage bargaining has been premised on the Riksbank achieving its inflation target. How wage-bargaining institutions work is highly consequential in a small economy with powerful labour market organizations, such as Sweden. A few years after the introduction of the bank's inflation target in 1993, Swedish trade unions and 
employer organizations began to assume that the target would be met, give or take, and they adjusted their wage negotiations accordingly. This high level of confidence in the Riksbank among powerful interest organizations was by no means a given. In the past, trade union leaders had been highly critical of the Riksbank's actions, accusing it of unduly prioritizing low inflation over high employment and low unemployment. By the late 1990s, however, the bank's inflation target had become a generally accepted anchor of inflation expectations, including within the labour movement (Bergström 1999: 79).

It is possible to track trends in the general public's confidence in Sweden's central bank over the last fifteen years. Starting in 2005, the nationally representative SOM surveys have asked about the public's views concerning the Riksbank (Tryggvason et al. 2014). As Fig. 5.1 shows, the Swedish public has considerable confidence in the central bank, at levels only slightly lower than its confidence in the police and the health-care system, which are among the social institutions in which Swedes have the most confidence.

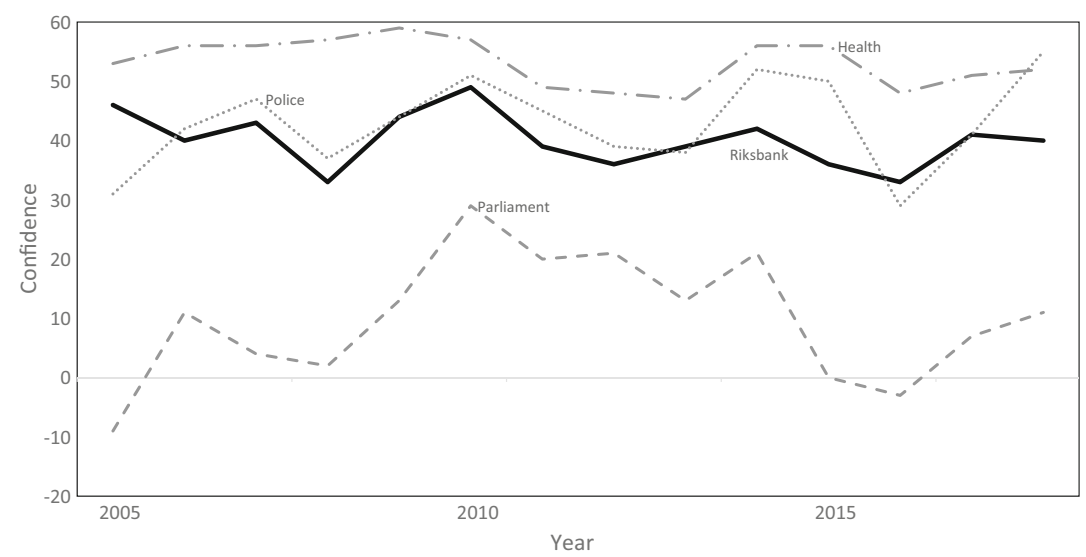

Fig. 5.1 Public Confidence in the Riksbank (Note The figure describes the percentage of survey respondents who say they have confidence in the Riksbank minus the percentage of survey respondents who say they don't. Data for 2013 are missing. The specific question is 'How much confidence do you have in how the following institutions and groups do their jobs?' Source The national SOM surveys, 2005-2018) 
The public's confidence in the Riksbank has been consistently higher than its confidence in parliament. Note that the level of public confidence in the Riksbank varies slightly over time. As one might have expected, for example, there was a dip in confidence in 2008, during the global and economic crisis commonly known as the Great Recession, but it soon recovered (Karlberg and Meyersson 2012).

There are a few noteworthy differences among different groups in the population. Table 5.1 describes the differences among the supporters of the eight political parties represented in the Swedish parliament (the data are from the autumn of 2018). As the table shows, ideologically centrist voters who support the two liberal parties-the Center Party and the Liberal Party-have the highest level of confidence in the Riksbank. Left-wing voters and radical-right voters supporting the Left Party and the Sweden Democrats, respectively, have the least confidence. But even among supporters of the Left Party and the Sweden Democrats, those who have confidence in the Riksbank outnumber those who do not.

Comments: The table describes the level of confidence in the Riksbank among the supporters of the eight parties that are represented in the Swedish parliament. The numbers are the percentage of each party's supporters who said that they were either 'highly confident' or 'fairly confident' in the Riksbank, minus the percentage who said that they had either 'fairly little confidence' or 'very little confidence'; in other words, positive numbers mean that those who were confident in the Riksbank outnumbered those who were not, and vice versa. The Center Party is an agrarian, liberal party. The Sweden Democrats are a populist radical-right party.

Table 5.1 Confidence in the Riksbank among Swedish voters

\begin{tabular}{lc}
\hline Supporters of... & Confidence $(-100$ to 100) \\
\hline Center Party & 69.7 \\
Liberal Party & 57.0 \\
Green Party & 57.6 \\
Conservatives & 51.1 \\
Social Democrats & 45.3 \\
Christian Democrats & 39.6 \\
Left Party & 14.9 \\
Sweden Democrats & 8.6 \\
\hline
\end{tabular}

Source The 2018 SOM survey 
Table 5.2 Levels of income, education and confidence in the Riksbank

\begin{tabular}{ll}
\hline Group & Confidence $(-100$ to 100) \\
\hline Low household income & 29.7 \\
Medium household income & 37.0 \\
High household income & 59.3 \\
Low education & 17.6 \\
Intermediate education & 42.6 \\
High education & 52.5 \\
\hline
\end{tabular}

Note The table describes the level of confidence in the Riksbank among groups defined by income and education. The numbers are the percentage of respondents in each group who said that they were either 'highly confident' or 'fairly confident' in the Riksbank, minus the percentage who said that they had either 'fairly little confidence' or 'very little confidence'; in other words, positive numbers mean that those who were confident in the Riksbank outnumbered those who were not, and vice versa

Source: The 2018 SOM survey

These patterns are explained in part by the evidence in Table 5.2, which breaks down confidence in the Riksbank by income (low, medium, high) and education (low, intermediate, high), using the standard categorization of income and education in the survey. As the table shows, high-income earners and-especially-the well-educated have more confidence in the Riksbank than individuals with low incomes and low education. Although the majority of people have confidence in the Riksbank across all segments of society, it is worth keeping in mind that even widely trusted and respected institutions such as Sweden's central bank enjoy higher levels of support in some groups than others.

\section{The Parliament's Bank}

The Riksbank has a long history (see Wetterberg 2009; Fregert 2018). The precursor of the Riksbank, a private bank called Stockholms Banco, was granted a royal charter in 1656. Stockholms Banco soon collapsed, but it was replaced, in 1668, by a new institution called Riksens ständers bank ('The Bank of the Estates of the Realm'), which was under the authority of three of the four estates that comprised Sweden's early-modern parliament: the nobility, the clergy and the middle-class 'burghers'. The fourth estate, the peasants, refrained from taking part 
in the banking venture, declaring, rather endearingly, that they didn't understand much about banking.

Ever since its beginnings in the 1660s, the Riksbank-which received its current name when the old estates parliament was abolished in 1866has been responsible to parliament and not to the king nor to government ministers. This sets the Riksbank apart from most other central banks in the world. ${ }^{4}$ Riksens ständers bank continued to operate both under the proto-parliamentarian political regime of Sweden's 'Age of Liberty' in 1718-1772, under the absolutist Gustavian regime that followed in 1772-1809, and under the constitutional monarchy that was established in 1809 . The 1809 constitution provided, in $\$ 72$, that Riksens ständers bank would 'remain, as it has been until now, under the protection and care of the Estates of the Realm'; in other words, parliament, not the king or his advisors, controlled the bank. ${ }^{5}$

The modern idea of central banks as banks with a monopoly on the release of paper money and with the role of lender of last resort within a wider banking system emerged during the nineteenth century. In Sweden, these ideas became law with the adoption of the 1897 Riksbank Act (Wetterberg 2009: 233-239).

The Riksbank's current tasks and responsibilities are defined by the Swedish parliament, the Riksdag, in The Sveriges Riksbank Act (Lag [1988:1385] om Sveriges riksbank) which was revised most recently in 2016. In 1999, the bank was made formally independent through the introduction of a new clause in Sweden's main constitutional document, the Instrument of Government. The clause provides that no other public authority may instruct the Riksbank on how to conduct its monetary policy. Like most other contemporary central banks, the Riksbank is thus operationally independent, although it remains constitutionally responsible to parliament.

An inflation target of two per cent, plus or minus one per cent, adopted in early 1993, has guided monetary policy ever since. The Riksbank estimates inflation expectations and sets interest rates on the basis of prognoses that draw on these estimates. This method of setting interest rates, known as 'inflation targeting', has become the standard procedure among modern central banks. In 1989, New Zealand was the first to embrace it, and the Riksbank joined the group of early adopters of inflation targeting a few years later (Truman 2003).

When studying an old institution such as the Riksbank it is tempting to attribute great explanatory power to the institution's origins, foundation 
and early history. In doing so, however, one runs the risk of committing the 'genetic fallacy', or, more generally, engaging in flawed anachronistic reasoning. That said, the fact that the Riksbank is primarily responsible to parliament and not to the government of the day or the monarch is a long-standing constitutional fact that has had important implications for the bank's standing and role in Swedish society, and it continues to do so today. Just as the 1809 constitution declared that the bank would 'remain' under parliament's 'protection and care', the current constitution, adopted in 1974, provides that the Riksbank 'is the central bank of the Realm and an authority under the Riksdag' (RF 9:13).

\section{The Politics of Independence}

Independence from political decision-makers inside the government and in parliament has been a salient issue throughout the Riksbank's long history. An independent central bank derives its legitimacy from technical expertise and good performance. This raises the question of how such a powerful, autonomous body fits into democratic institutional structures in which the main source of legitimacy is popular sovereignty.

Curiously, the Riksbank's autonomy and operational independence have varied over time in a manner that has reflected changes in the bank's physical location. For more than two centuries, the Riksbank operated out of an Italianate building at Järntorget 84, in the part of Stockholm that is now known as the 'old town'. In 1905, it moved half a kilometre north-northwest, to the new Parliament House on Helgeandsholmen. The bank's most recent move, a further half-kilometre north-north-west, was in the 1970s: the current rock-clad, imposing central-bank building at Brunkebergs torg was completed in 1976 (on the Riksbank's various buildings since 1668, see Larsson 1976). When parliament returned to Helgeandsholmen from temporary accommodations at Sergels Torg in 1983, there was again a half-kilometre distance between parliament and the central bank. The five hundred metres that today separate the Riksbank from parliament and from the Prime Minister's office are a symbol of political and institutional independence. ${ }^{6}$

One important event occurred in 1957 when the Riksbank's General Council-which made operational monetary policy decisions at that time-raised the interest rate from 4 to $5 \%$ without first consulting the finance minister or the prime minister (Carlsson 1993). This decision followed an intense debate over monetary policy among politicians and 
in the newspapers. The political parties, leading economists and various media outlets soon took sides in the struggle between the bank and the government. The end result was that the chairman of the General Council, Per Eckerberg, resigned. Significantly, however, the central bank governor, Per Åsbrink, did not resign, although several prominent politicians maintained that he should. In a sense, therefore, the 1957 interest rate coup', as it would become called, manifested the central bank's relative independence. The coup marked the end of low-interest-rate policies that the Social Democrats and the Farmers' Party had pursued in the 1950s, in combination with detailed regulations of the financial system.

By the 1990s, in spite of significant disagreements between the Riksbank and both centre-right and social democratic governments, it had become unthinkable for the government to instruct the Riksbank on how to conduct monetary policy. In November 1993, for example, under a centre-right government, the Finance Ministry prepared a memo on the relationship between the government and the central bank and concluded that exerting pressure on the bank 'would be a minor disaster'. Leif Pagrotsky, a leading economic adviser to the Social Democrats, who formed a new government the following year, noted that by that time, the Riksbank didn't take orders from anyone, that it said what it wanted, and that the government had no choice but to adjust to what it said and did (Lindvall 2004: 122).

In constitutional and legal terms, however, the central bank only gained full independence in 1999. A 1993 government commission of inquiry (SOU 1993:20) had concluded that the central bank should be made independent. The Social Democratic members of that commission resisted independence and filed a dissenting opinion. Nevertheless, a few years later, it was a Social Democratic government that introduced central-bank independence. One of the main reasons for this change in policy was that Sweden had joined the European Union in 1995. Leading Social Democrats regarded central-bank independence as a legal obligation under the EU treaties. This included Jan Bergqvist, who was one of the Social Democrats who wrote a dissenting opinion in 1993 and who chaired the parliament's standing committee on finance. There were also prominent groups within the Social Democratic party who believed that central-bank independence would offer economic and political benefits, much like New Labour did when it made the Bank of England independent soon after winning power in 1997. 
When a more recent Social Democratic government commissioned a review of Sweden's monetary policy framework in 2016, it stated explicitly that the Riksbank should remain independent. By now, centralbank independence was the unassailable starting point for any discussion about economic policy. It was no longer to be questioned. Interestingly, when the final report of this commission was released in the autumn of 2019 (SOU 2019:46), there was only one dissenting opinion-by Johan Lönnroth, a former deputy leader of the Left Party-and that dissenting opinion did not propose reducing the Riksbank's independence (it only suggested that the inflation target should be combined with an employment target) (1877-1878).

\section{Rising to the Challenge of Economic Crisis}

\section{The 1991-1993 Recession}

The growing authority of the Riksbank in Sweden's political system is best explained by two crisis episodes in the 1990s and the 2000s in which the bank was seen to act firmly and effectively. The first was the aftermath of the exceptionally deep economic crisis in Sweden in the early 1990s. In 1991-1993, Sweden experienced three consecutive years of negative growth. Unemployment increased from less than two per cent to approximately $10 \%$ of the labour force. In the beginning of this crisis, the centre-right government, the Social Democratic opposition and the Riksbank were all convinced that maintaining a fixed exchange rate was essential for economic stability. They were wedded to a 'German model' of economic governance (Stern and Sundelius 1997: 38). During the most acute phase of the crisis, the Riksbank took drastic steps to defend the exchange rate, at one point even raising the short-term interest rate to $500 \%$. But the government and the Riksbank were ultimately unsuccessful in their efforts. Sweden was forced to abandon its fixed exchange rate on 19 November 1992.

It was the Riksbank's actions in the aftermath of the most acute phase of the crisis - the product of a fast learning curve following its fruitless attempt to 'defend the Swedish Crown'-that mattered the most for subsequent events. Immediately after floating the Crown, the government's view was that Sweden should return to some form of fixed exchange rate. For example, on 20 November 1992, the day after the float, the Prime Minister wrote in an email to the Finance Minister 
that Sweden should join the European Exchange Rate Mechanism, the precursor of the Euro, as soon as possible. Meanwhile, however, the Riksbank took immediate steps to introduce the 2-plus-or-minus- $1 \%$ inflation target that it has followed ever since, and adopted new methods of inflation targeting, following speedy communications with other central banks that had already introduced this method of conducting monetary policy (for an overview of these events, see Andersson 2003).

In the wake of the float, the Riksbank thus abandoned the prevailing orthodoxy of Swedish macroeconomic policy, which was to achieve economic stability in Sweden by aligning its economic policies with those of its European partners, especially Germany. After the economic crisis, generations of Swedish policymakers have regarded the rapid reorientation of economic policy after the crisis as essential to Sweden's subsequent economic success (Lindvall 2008). In a 2000 government report, for example, the Swedish government reflected on the conduct of its economic policy throughout the previous decade. In that report, the section on how Sweden got out of the deep crisis begins-in its very first sentences - with the Riksbank's adoption of the new inflationtargeting policy in 1993 (Prop 2000/2001:100, Appendix 5:21-22). The bank's inflation-targeting policy was, similarly, the first topic of a speech on Swedish economic policy by the first deputy governor of the Riksbank, Cecilia Skingsley, in early 2020, almost thirty years after the policy was put in place. She illustrated its beneficial effects with numerous graphs that compared inflation, growth, real wages and the current account balance before and after the early 1990s (Skingsley 2020).

These experiences from the 1990s are a good example of the institutionalization process that was described in Chapter 1 of this volume. According to the argument made there, a cycle of institutionalization starts with the discovery or invention of an effective, efficient and legitimate way to reconcile formal aims with societal aspirations through a mix of experimentation and smart copying. After abandoning the fixed exchange rate, the Riksbank immediately sent officials to their counterparts in New Zealand's and Canada's central banks to learn from their experiences, and adapt the lessons learnt to Swedish conditions. The next step in the institutionalization process is that successful practices 'give rise to the emergence of an internal norm' that say 'this is how we do things around here'. As the documents and speeches cited above suggest, that is what happened with the Riksbank and its role within Sweden's political system after the deep crisis of the 1990s. The adoption of a new monetary 
policy strategy so quickly after the failure of the previous fixed-exchangerate policy was a formative event that has shaped monetary policymaking since.

The two subsequent steps on the institutionalization ladder concern building an organization that embodies the new norm and promoting the norms and practices within the new, or altered, organization. This process unfolded in the 1990s and early 2000s, a period in which the Riksbank was headed by Urban Bäckström, a former centre-right economic and political adviser who was appointed governor in 1994, and Lars Heikensten, a former social-democratic political and economic adviser who eventually replaced Bäckström. Notably, many of the leaders who had been responsible for monetary policy in the period leading up to the failed defence of the fixed exchange rate in 1992 left the bank soon thereafter. For the new leadership, the switch to a floating exchange rate and the adoption of a policy of inflation targeting represented an opportunity to bring about wider changes - not just a discrete change in policy but a new monetary policy regime, which they sought to consolidate within the bank and communicate to other stakeholders (for a discussion of this process, see, for instance, Heikensten 2003).

The development of a new communication strategy with the general public and with market actors has been an important element in the Riksbank's evolution as an institution after the mid-1990s (Karlberg and Meyersson 2012). Indeed, there is something almost paradoxical about the differences between the pre-independence period and the current period of independence. Before the mid-to-late 1990s - when the central bank was not formally independent-monetary policy and exchange-rate policy were typically treated as opaque and mysterious in media coverage. Subsequently, political debates about Sweden's monetary policy have become more transparent and accessible to the public. The goal of low and stable inflation is easier to understand than the earlier exchange-rate target, and the Riksbank has increased the transparency of its methods of monetary policymaking. In a sense, then, the Riksbank has turned itself into a more responsive institution on one dimension (public transparency and accountability) while becoming less responsive on another (democratic political control).

It is often assumed that the delegation of policymaking authority to central banks or other autonomous agencies is motivated and justified by the expertise those organizations possess. Politicians set broad targets and then let skilled and trained professionals carry out actual policy. But 
that is not the only or even the main reason that politicians assign this role to independent central banks or other agencies (Majone 1996). The main reason is that some forms of partisan political conflict are thought to be harmful to a country's long-term economic interests, even if partisan conflict in general is necessary and legitimate in a democracy.

In the 1970s, 1980s and 1990s, there were recurring political conflicts within Sweden over economic policy, not only among the political parties on the left and on the right but also among the powerful interest organizations in Swedish society. Governments struggled to find a way of containing those conflicts, preventing rising inflation and avoiding recurring macroeconomic instability. Until the early 1990s, left-wing governments, right-wing governments and the Riksbank hoped, as discussed earlier, that a commitment to a fixed exchange rate would solve this problem.

When that strategy failed in 1992, the Riksbank proved to be agile. Facing new, harsher economic realities than its long-held policy orthodoxy had presumed, it quickly shifted its attention to the policy of inflation targeting that it has pursued ever since. This is a policy that serves to address the same set of problems, but in a way that has proven more reliable and viable in the long run. In spite of recurring debates over the conduct of monetary policy in the years since, the Riksbank's contribution to finding a way out of the political and economic impasse of the 1990s has made it the trusted and respected institution that it today.

\section{The Post-2008 Great Recession}

The next major economic crisis that struck Sweden after the deep economic downturn in 1991-1993-and the lengthy unemployment crisis that followed-was the Great Recession, which began with the breakdown of the global financial system following the collapse of the US investment bank Lehman Brothers in September 2008. Unlike the 19911993 crisis in Sweden, the Great Recession was a global crisis, but there were also some important similarities. Just like the home-grown Swedish crisis some fifteen years earlier, the Great Recession began in the financial market, as banks and financial institutions struggled with bad debt due to falling real-estate prices and these problems in the financial market then spread to the real economy. Due to these similarities, the Riksbank officials and former politicians and government officials were much 
in demand in other countries during the Great Recession. For example, Bo Lundgren, who was the minister responsible for financial markets in the early 1990s, working closely with the Riksbank, testified before US Congress in 2009.

The Riksbank pursued aggressive monetary policies in response to the crisis. Immediately after the collapse of Lehman Brothers, the Riksbank combined with other central banks around the world to lower interest rates drastically (see Fig. 5.2). In late 2010, the Riksbank began to raise interest rates again, judging, as many other central banks and governments did around that time, that the acute phase of the crisis was over. But in 2011-2012, as a result of the European debt crisis, interest rates started to come down again.

In early 2015, the Riksbank cut the main short-term lending rate, the 'repo' rate, to $-0.10 .^{7}$ This made the Riksbank the first central bank in the world to introduce negative interest rates. The main lending rate remained negative from 2015 until December 2019, when the bank adopted an interest rate of $0 \%$. In the decade following the outbreak of the Great Recession, the Riksbank also implemented other unconventional forms of monetary policy, such as direct purchases of government bonds.

The Riksbank's aggressive policies were enabled by the confidence that the bank had gained following its handling of Sweden's home-grown economic crisis in the 1990s, and by the institution building that occurred in its wake. The bank's leaders publicly retained their commitment to the inflation-targeting regime that had become the new orthodoxy, but at the same time allowed the probing of its merits under the new, this time global, economic crisis, through rigorous internal debate over the conduct of monetary policy.

\section{DEBATES AND INNOVATIONS}

The debates over the bank's monetary policies in the 2000s reveal how an established institution such as the Riksbank handled internal disagreements and tensions. As Fig. 5.2 shows, the Riksbank opted for a more restrictive monetary policy beginning in 2010, and only reduced the interest rate to the low levels of 2008-2010 some four-five years later. In the very first phase after the Lehman Brothers collapse, Lars E. O. Svensson-an internationally renowned economist who was on the governing board of the Riksbank at the time-advocated even lower 
126 J. LINDVALL

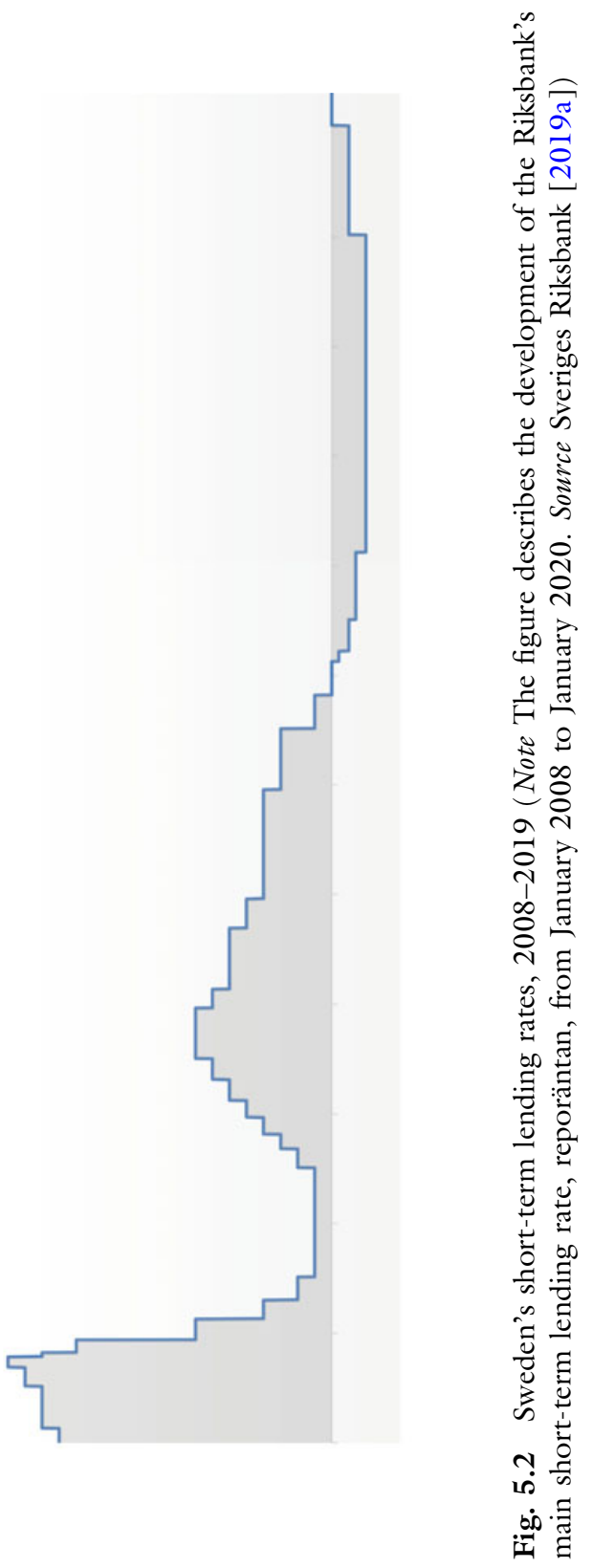


interest rates. When the interest rate increased after 2010, the debate within the central bank became more heated. Svensson was joined by another member of the governing board, Karolina Ekholm.

The governing board was thus divided between a 'dovish' minority and a 'hawkish' majority. In Lars E. O. Svensson's view, the majority's policy decisions had led to several years of unnecessarily high unemployment (Svensson 2014). The majority was more concerned about rising household debt and believed that high interest rates were necessary to discourage households from excessive borrowing (see, for example, Jansson 2014). The majority view, then, was that the rapid increase in house prices justified a higher interest rate; the minority argued that the Riksbank should concentrate on the inflation target and that monetary policy could not be used to safeguard financial stability.

This was not just a debate over policy. Implicitly, it was also a debate over the bank's general standing and role. Contemporary Sweden has a monetary policy regime that is based on a flexible exchange rate, a clear inflation target, and a limited set of instruments (mainly the policy rate), with a mandate for the bank leadership to decide independently how the few instruments at the bank's disposal are to be used to achieve the inflation target. This was the model that the Riksbank and successive governments consolidated during the late 1990s and in the 2000s. It was a mutually attractive model since elected politicians could concentrate on distributional politics while the Riksbank's policies determined the playing field on which they could operate, and did so in a fairly transparent and predictable manner.

If the bank had taken a significantly broader view of its mandate, as the majority's view implied it should, it would have made the bank's policies much more politically controversial. First, the bank would have had to weigh different goals against each other, which in itself is politically sensitive. Second, house prices would at least implicitly have become a target for interest rate policy, which has obvious distributional policy implications. A large proportion of Swedish households' wealth is sunk into their homes. As it happened, the debate within the bank petered out after Svensson's decision to leave the governing board in 2013-a decision that was a direct consequence of the disagreements within the bank. Somewhat ironically, the bank soon after adopted more aggressive, expansionary policies-policies that were more closely aligned with those Svensson had favoured. 
By the late 2010s, the so-called e-krona project provided more evidence of the Riksbank's willingness to engage in innovative policies and programs. It revolves around the idea of creating a central-bank issued electronic currency, the e-krona. Were the Riksbank to go through with this reform, the e-krona would represent the world's first governmentissued electronic currency. The e-krona would compete with electronic money created by banks and other private organizations (through debit and credit cards, for instance) and also with private electronic currencies such as Bitcoin and the Facebook corporation's Libra.

The Riksbank's motivation for this project is that Sweden is rapidly shifting away from paper money to electronic payments. Sweden, in fact, uses less cash than any other country on Earth. An increasingly cashless society makes it more difficult for the bank to guarantee the system of payments in the economy. The e-krona is meant to address this concern (Sveriges Riksbank 2017). Another reason for the bank's e-krona initiative is that the conditions of monetary policy, which is the bank's main responsibility, might change in important ways in an economy with no or little government-backed money (Sveriges Riksbank 2018).

The e-krona project, if implemented, would have important implications that reach far beyond Sweden. Through the rapid move away from coins and paper money, the state's traditional role of issuing money is being undermined, and the creation of money is being taken over by the private corporations that oversee credit card payments and electronic transactions. In that sense, the idea of introducing an e-krona is an attempt to reassert public authority in a world where private interests and organizations are ascendant. ${ }^{8}$

Why is the Swedish central bank developing this project of government-backed electronic money, and not the larger central banks in the larger economies of Europe and North America? The main reason is most likely that paper money is disappearing more rapidly in Sweden than in other advanced economies (as noted, for example, by Heller 2016). In that sense, the problem that the Riksbank is seeking to address with the e-krona project has greater urgency in Sweden than elsewhere. But there were other reasons as well, notably the Riksbank's strong status in Swedish society and its desire to be an 'inventive, highly prepared and responsive central bank' (see the Riksbank's strategic plan for 2019-2022: Sveriges Riksbank 2019b). 


\section{InSTITUTIONALIZING CENTRAL BANKS: LESSONS FROM THE SWEDISH CASE}

In 2018, the Riksbank celebrated its 350th birthday in good health. Its autonomy was respected by the elected government, it managed private-sector expectations about future price levels, and inspired confidence among the public. This chapter has documented many important similarities between the Riksbank's institutional trajectory and the stylized description of a typical institutionalization cycle presented in the introductory chapter of this volume.

When it comes to potential threats to the Riksbank, and to similar institutions, the profound internal debates over the bank's monetary policies in the 2010s highlighted an important dilemma for independent institutions. The majority on the bank's governing board was concerned about rising household debt and wished to use monetary policy to keep households from borrowing too much. The critics, on the other hand, suggested that such a policy was inconsistent with the bank's inflation target and argued that household debt was a problem for other institutions to solve.

This was not merely a disagreement over economic policy, but a deeper, constitutional disagreement about the institutional role and position of a central bank. In a democratic system, institutions based on autonomous expertise, such as central banks, always maintain an uneasy relationship with governments and elected politicians. The majority's views on the conduct of monetary policy were motivated by important policy concerns, but they also carried an important risk. If the Riksbank had extended its power into new domains, it would have become more difficult to maintain the delicate balance between expertise and popular sovereignty that modern central banks depend on-both for their political autonomy and for their attempts to maintain the confidence of the general public (Woodford 2003).

It has become increasingly common for national governments to delegate important policymaking competencies to central banks, other independent agencies and international organizations. By identifying problems that national governments have trouble solving, and handing over the management of those problems to independent decision-makers, governments hope to make their long-term policies more credible and durable (Majone 1998; Moravcsik 2002). Modern central banks are the clearest examples of this governance model, but there are other examples. 
One conclusion from this chapter is that such delegation to independent agencies need not be premised on consensus over policy, nor does it imply that experts are better able to conduct policy than politicians are. Instead, institutions such as the Riksbank have gained independence, and enjoy widespread respect, because they have a reputation for being able to manage and contain ongoing conflicts over economic policy that are endemic in a democratic society. The future of the Riksbank will depend on the continued willingness and capacity of its leadership to play this role, while at the same time adapting its repertoires and capabilities to fast-paced technological change.

\section{QUESTIONS FOR Discussion}

1. Public-opinion surveys suggest that most Swedes have high confidence in their central bank, the Riksbank. But there are significant differences among different groups, and individuals with low incomes and little education trust the Riksbank less than welleducated high-income earners. When do these sorts of differences become a long-run threat to institutions?

2. Modern central banks typically seek to maintain their operational independence from parliaments and governments. What do institutions whose legitimacy relies on expertise need to do to maintain their autonomy within political systems where the main source of legitimacy is democratic elections and popular will?

3. How do trusted and effective institutions communicate their strategies and intentions to political decision-makers, business organizations and other stakeholders and to the general public?

4. The Riksbank has been widely credited for saving the Swedish economy in 1992. How did the bank do this and how has this performance affected its institutional status?

5. The Riksbank's e-krona project has met with significant criticism among commentators and stakeholders who believe that it is risky and radical, but so far, the Riksbank has maintained that the ekrona is a necessary step to take because of rapid technological and economic change. How do successful institutions strike a balance between maintaining their core competencies and adapting to a changing world? 


\section{Notes}

1. In my own discipline of political science, institutions are typically defined as rules-written or unwritten-and not as organizations. In this chapter, in a manner consistent with the book's terminology, I use the term in the sociological sense of 'responsive, adaptive organism' (Selznick 1957: 5).

2. For a recent history of the Riksbank in English, see Fregert (2018); for a more detailed history in Swedish, see Wetterberg (2009).

3. The goals are defined in Chapter 1, article 3 of The Sveriges Riksbank Act (Lagen [1988:1385] om Sveriges Riksbank).

4. During some of the more absolutist phases in Sweden's early-modern history, as Wetterberg (2009) notes, the bank remained formally responsible to parliament, but de facto, the monarch exercised a great deal of influence; see, for instance, 53-54 on Charles XI and 68-74 on Charles XII; but see also p. 129 on the bank's relative autonomy under Gustav III.

5. 'Riksens ständers bank förblifver hädanefter, som den hittills varit, under riksens ständers egen garanti och vård'.

6. For a discussion of the Riksbank's role and independence in the beginning of the twentieth century, see Cassel (1908).

7. This was actually not the first time that the bank pursued a policy of negative interest rates, since the bank's overnight-deposit rate is typically 0.5 percentage points lower than the repo rate.

8. The e-krona project is not uncontroversial. When the Riksbank's second report on the e-krona project was issued in late 2018, corporations, special interest groups and public agencies were invited to comment on the proposal. Several of the replies were critical of the project, but it is moving forward nevertheless. In December 2019, the Riksbank announced that it had commissioned the international consultancy Accenture to develop an e-krona trial in a laboratory environment.

\section{REFERENCES}

Adolph, C. (2013). Bankers, Bureaucrats, and Central Bank Politics. Cambridge: Cambridge University Press.

Andersson, K. (2003). Utformningen av inflationsmålet och den penningpolitiska analysramen. In L. Jonung (Ed.), På Jakt efter ett Nytt Ankare (pp. 223-279). SNS Förlag: Stockholm.

Bergström, V. (1999, mars 17). Optimist. Proceedings of the seminar Med backspegeln som kompass: Ett ESO-seminarium; Rosenbad. Rosenbad: ESO, p. 79.

Carlsson, B. (1993). Den Enprocentiga Revolutionen: Debatten om Riksbankens Ställning i Samband med Räntekuppen 1957 (Lund Papers in Economic History No. 26). Lund, Sweden: Lund University. 
Cassel, G. (1908). Riksbanken under Krisen 1907-1908. Stockholm: Geber. Cukierman, A. (1992). Central Bank Strategy, Credibility, and Independence. Cambridge, MA: MIT Press.

Edvinsson, R., Jacobson, T., \& Waldenström, D. (Eds.). (2018). Sveriges Riksbank and the History of Central Banking. Cambridge: Cambridge University Press.

Fregert, K. (2018). Sveriges Riksbank: 350 years in the making. In R. Edvinsson, T. Jacobson, \& D. Waldenström (Eds.), Sveriges Riksbank and the History of Central Banking (pp. 90-142). Cambridge: Cambridge University Press.

Goodsell, C. T. (2011). Mission Mystique: Belief Systems in Public Agencies. Washington: CQ Press.

Hall, P. A., \& Franzese, R. J. (1998). Mixed signals: Central bank independence, coordinated wage bargaining, and European Monetary Union. International Organization, 52(3), 505-535.

Heikensten, L. (2003) Bakom riksbankens tjocka väggar. In L. Jonung (Eds.), På Jakt efter ett Nytt Ankare (pp. 331-375). Stockholm: SNS Förlag.

Heller, N. (2016, October 10) Cashing Out. The New Yorker. https://www.new yorker.com/magazine/2016/10/10/imagining-a-cashless-world. Accessed 13 March 2020.

Jansson, P. (2014). Hur stoppar vi trenden i hushållens skulder? Ekonomisk Debatt, 42(3), 49-62.

Karlberg, P. P., \& Meyersson, P. (2012). En Resa i Kommunikation. Fallet Sveriges Riksbank. Stockholm: SNS Förlag.

Larsson, L. O. (1976). The Riksbank and its Buildings. In I. Henrikson \& L. Karlson (Eds.), Sveriges Riksbank, Its Buildings, 1668-1976 (pp. 27-100). Sveriges Riksbank: Stockholm.

Lindvall, J. (2004). The Politics of Purpose (Dissertation). University of Gothenburg, Gothenburg.

Lindvall, J. (2008). Sweden: Stability without Europe. In K. Dyson (Ed.), The Euro at Ten: Europeanization, Power, and Convergence (pp. 307-321). Oxford: Oxford University Press.

Majone, G. (1996). Temporal consistency and policy credibility: Why democracies need non-majoritarian institutions (RSC Working Paper No. 96/57). Florence, Italy: European University Institute.

Majone, G. (1998). Europe's 'democratic deficit'. European Law Journal, 4(1), 5-28.

Marcussen, M. (2005). Central banks on the move. Journal of European Public Policy, 12(5), 903-923.

Moravcsik, A. (2002). Reassessing legitimacy in the European union. Journal of Common Market Studies, 40(4), 603-624.

Selznick, P. (1957). Leadership in Administration: A Sociological Interpretation. New York: Harper \& Row. 
Skingsley, C. (2020, January 28). Vägen från finanskrisen och framåt. Speech at Berns, Berzelii park. Stockholm.

Stern, E., \& Sundelius, B. (1997). Sweden's Twin Monetary Crises of 1992. Journal of Contingencies and Crisis Management, 5(1), 32-48.

Svensson, L. E. O. (2014). Riksbanken, måluppfyllelsen och den demokratiska kontrollen. Ekonomisk Debatt, 42(4), 54-66.

Sveriges Riksbank. (2017, September). Riksbankens e-krona projekt: rapport 1. Sveriges Riksbank. https://www.riksbank.se/sv/betalningar-kontanter/ e-krona/e-kronarapporter/e-kronaprojekt-rapport-1/. Accessed 20 March 2020.

Sveriges Riksbank. (2018, October). Riksbankens e-krona projekt: rapport 2. Sveriges Riksbank. https://www.riksbank.se/sv/betalningar-kontanter/ e-krona/e-kronarapporter/e-kronaprojekt-rapport-2/. Accessed 20 March 2020.

Sveriges Riksbank. (2019a, February 14). Annual Report for Sveriges Riksbank 2018. Sveriges Riksbank. https://www.riksbank.se/en-gb/press-andpublished/publications/annual-report/. Accessed 20 March 2020.

Sveriges Riksbank. (2019b, March 1). Strategic plan. Sveriges Riksbank. https://www.riksbank.se/en-gb/about-the-riksbank/policy-documents/str ategic-plan/. Accessed 19 March 2020.

Truman, E. M. (2003). Inflation Targeting in the World Economy. Washington, DC: Institute for International Economics.

Tryggvason, N. O., Bergström, A., \& Ohlsson, J. (2014). Förtroendet för Riksbanken. SOM-rapport nr 2014:16. SOM-Institutet/Göteborgs Universitet. https://som.gu.se/publicerat/rapporter/?languageId=100000\&disableRedir ect=true\&returnUrl=http\%3A\%2F\%2Fsom.gu.se\%2Fsom_institute\%2Fpublica tions\%2Freports\%2F\%3FlanguageId\%3D100001. Accessed 20 March 2020.

Wetterberg, G. (2009). Money and Power: From Stockholm's Banco 1656 to Sveriges Riksbank today. Stockholm: Atlantis.

Woodford, M. (2003). Interest and Prices. Princeton: Princeton University Press. 
Open Access This chapter is licensed under the terms of the Creative Commons Attribution 4.0 International License (http://creativecommons.org/licenses/ by $/ 4.0 /$ ), which permits use, sharing, adaptation, distribution and reproduction in any medium or format, as long as you give appropriate credit to the original author(s) and the source, provide a link to the Creative Commons license and indicate if changes were made.

The images or other third party material in this chapter are included in the chapter's Creative Commons license, unless indicated otherwise in a credit line to the material. If material is not included in the chapter's Creative Commons license and your intended use is not permitted by statutory regulation or exceeds the permitted use, you will need to obtain permission directly from the copyright holder.

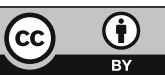

